\title{
K nálezu básnických rukopisov Pavla Országha Hviezdoslava $^{1}$
}

\author{
Anna Zelenková (Praha)
}

\begin{abstract}
Abstrakt
Štúdia sa zaoberá osudom rodinnej nearchivovanej pozostalosti českého literárneho historika Alberta Pražáka (1880-1956), ktorý stál na začiatku literárnovedného záujmu českej strany o osobnost' jedného z najvýznamnejších slovenských básnikov Pavla Országha Hviezdoslava (1849-1921) a venoval mu i spomienkovú publikáciu S Hviezdoslavom (1955). Aj ked’ Pražák odovzdal v pätdesiatych rokoch 20. stor. na Slovensko rozsiahly konvolút slovacík týkajúcich sa tvorby Hviezdoslava, o. i. si čast' jeho raných básní ešte ponechal na d’alšie študijné účely. Tak sa v jeho osobnej pozostalosti v súčasnosti objavil súbor niekolkých desiatok neznámych slovenských a mad’arských básní P. O. Hviezdoslava z prelomu šest'desiatych a sedemdesiatych rokov 19. stor. V lyrických textoch dominujú najmä prírodné a lúbostné motívy zachytávajúce autentický zážitok; básne poukazujú na básnický talent začínajúceho autora. Uverejnenie a interpretácia básnických prvotín síce celkovo nezmení pohlad na autorovu tvorbu, ale prispeje k hlbšiemu pochopeniu jeho umeleckého formovania.
\end{abstract}

\section{Kl'účové slová}

Pavol Országh Hviezdoslav; rodinná pozostalost' Alberta Pražáka; neznáme rukopisy P. O. Hviezdoslava, československé literárne vztahy

\section{Abstract \\ On the Finding of Pavol Országh Hviezdoslav's Poetic Manuscripts}

The paper explores the fortunes of the unarchived family inheritance of Albert Pražák (1880-1956), the Czech literary historian who initiated Czech literary research into the creations of the most accomplished Slovak poet P. O. Hviezdoslav (1849-1921). Namely, in his memorial publication S Hviezdoslavom (1955). Having delivered a comprehensive set of Slovak archive materials related to Hviezdoslav to Slovakia in the 1950s, Pražák retained, among others, some of Hviezdoslav's early poems for further study. This explains why Pražák's personal inheritance has now produced a few dozens of Hviezdoslav's unknown Hungarian and Slovak poems, written at the turn of 1870s. The dominant element in his lyrics are mainly natural and love motifs reflecting an authentic experience, and poems that reveal the young poet's creative skills. A successive publication and interpretation of Hviezdoslav's juvenilia can hardly change the assessment of his poetry, nevertheless it may facilitate deeper understanding of his artistic formation.

\section{Key words}

Pavol Országh Hviezdoslav; Albert Pražák's family inheritance; unpublished manuscripts by Hviezdoslav; Czech-Slovak literary relations

1 Čast̉ rodinnej pozostalosti (slovaciká) po Albertovi Pražákovi, ktorá zostala po jeho smrti v rodinnom archíve, získala autorka tejto štúdie od jeho dcéry Hany Drábkovej-Pražákovej pri osobnom stretnutí. V konvolúte slovacík objavila aj súbor rukopisov básnických textov P. O. Hviezdoslava z úvodnej etapy jeho tvorby, niekol'ko korešpondenčných jednotiek od básnika a jeho ženy Ilony Országhovej atd'. Celý súbor slovacík z Pražákovej nearchivovanej pozostalosti je uložený u A. Zelenkovej. 
V dejinách česko-slovenských literárnych vztahov môžeme nájst̉ určité ikonické dvojice, t. j. často uvádzané príklady osobných kontaktov, úzkej spolupráce či vzájomného ovplyvňovania, ktoré sa objavujú v literárnych dejinách, napr. ako odkaz na doplnenie vývojových medzier (komplementárna funkcia v diele K. H. Máchu a K. Kuzmányho), empirické doklady genetických kontaktov a typologických analógií (napr. O. Březina x I. Krasko), alebo kultúrno-politické príspevky k rozvoju literárnej vzájomnosti (A. Pražák x P. O. Hviezdoslav a pod.). Práve posledná dvojica sa stala v medzivojnovom období 20. storočia akýmsi kanonizovaným symbolom ideálneho vztahu a spolupráce českých intelektuálov a slovenských spisovatelov, ktorí oficiálne reprezentovali myšlienku národnej jednoty kultúrnej politiky novovytvoreného Československa. Najväčšiu zásluhu na tejto „legende“ jednoty (navonok podporovanej aj jedným z najvýznamnejších slovenských básnikov P. O. Hviezdoslavom) mal český literárny historik Albert Pražák (1880-1856), ktorý v rokoch 1921-1933 pôsobil ako riadny profesor českej a slovenskej literatúry na novozaloženej Filozofickej fakulte Univerzity Komenského v Bratislave. Jeho rozsiahle vedecké dielo bolo síce metodologicky späté s pozitivizmom, ale predsa len otváralo aj nové otázky, ktorých riešenie súviselo s aktuálnymi hodnotami národného osudu a kultúrneho dedičstva. Po roku 1918 transformoval politickú myšlienku jednotného československého národa do intelektuálnej roviny, tzn. do konštituovania „československej“ literatúry ako estetického a ideového výrazu dvoch integrálnych a rovnocenných vetiev spoločného celku, v ktorom však priznával hodnotovú dominanciu českému písomníctvu. V roku 1933 odišiel z Bratislavy na Filozofickú fakultu Karlovej univerzity v Prahe, kde mal ako nástupca zakladatelov českej literárnej historiografie Jaroslava Vlčka a Jana Jakubca prispievat k tomu, aby na akademickej pôde aj v širšej kultúrnej verejnosti „utužil národni, kulturni a politickou jednotu československou“2. Práve A. Pražák je osobnostou, ktorá stála na začiatku literárnovedného záujmu českej strany o P. O. Hviezdoslava; je známy svojím velmi blízkym, priatel'ským vztahom s týmto básnikom - dokonca od neho získal pre svoje štúdium aj množstvo nepublikovaných rukopisov z raného obdobia tvorby.

Básnické dielo Pavla Országha Hviezdoslava (1849-1921) vyvolávalo už od začiatku záujem domácej literárnej kritiky, ktorý sa potom odrazil nielen vo vel'kom počte literárnoteoretických interpretácií, ale aj v rozsiahlom heuristickom výskume a postupnom archívnom a publikačnom sprístupňovaní známych i neznámych textov. Hviezdoslavovo dielo, a to napriek tomu, že existujú edičné komplety Zobrané spisy básnické 1-15 (Martin, 1892-1931) a Spisy P. O. Hviezdoslava v 12 zväzkoch (Martin - Bratislava, 1951-1957), Hviezdoslav 1-4 (Bratislava, 1973) atd'. a reprezentatívne výbery z epickej a lyrickej básnickej tvorby, ktorej počiatky mapovali najmä výbery doteraz najvýraznejšieho znalca celkového básnikovho diela Stanislava Šmatláka (Básnické prvotiny 1-2, Bratislava, 1955-1956; Básnické zrenie 1-2, Bratislava, 1957-1958; Hviezdoslav. Zrod a vývin jeho lyriky, 1961), nevyšlo doteraz knižne vo svojej úplnosti. Sporadické nálezy d’alších autorových básnických textov zo sedemdesiatych a osemdesiatych rokov 19. storočia, písaných okrem slovenčiny aj po mad’arsky a nemecky, prispeli k hlbšiemu poznaniu Hviezdoslavovho umeleckého vývinu, no celkovo však už nezmenili poetologickú a literárnohistorickú charakteristiku

2 Citované podla posudku komisie pre inauguračné konanie Alberta Pražáka na Filozofickej fakulte Karlovej univerzity v Prahe (Archív Karlovej univerzity v Prahe - Osobný fond A. Pražáka). 
spisovatelovej tvorby. Postupné objavovanie nepublikovaných raných básnických pokusov je pravdepodobne dôsledkom autorovej sebakritickosti i neochoty publikovat svoje „učňovské“ texty, ktoré niekedy označil v listoch Albertovi Pražákovi za „naivné, nevyspelé [...] črre banality [...]", ${ }^{3}$ ale aj, ako je zrejmé, v ešte stále nekompletnom zmapovaní a archivovaní rukopisov a materiálov z pozostalosti P. O. Hviezdoslava, ktoré sa môžu nachádzat mimo muzeálne archívy, a to aj v súkromnom (literárnovednej verejnosti neznámom) majetku. A navyše tu až na výnimky prevládali názory, ktoré považovali autorove rané texty v komparácii s jeho neskorším vývojom za zaujímavú, ale uzatvorenú samostatnú kapitolu, od ktorej sa básnik vo svojom vrcholnom tvorivom období „dištancoval“, a preto nebolo nutné túto počiatočnú etapu umeleckého formovania v komplexnosti textovo a heuristicky dokumentovat. ${ }^{4}$ Iba hlavný editor (a jeden z najväčších znalcov) Hviezdoslavovho diela Stanislav Šmatlák už od pätdesiatych rokov 20. storočia pri vydávaní materiálu z pozostalosti neustále upozorňoval na pozvol'ný prechod medzi „nezrelostou“ a „majstrovstvom“ i na to, že je nevyhnutné analyzovat úvodnú fázu Hviezdoslavovho formovania aj v súvislosti s celkovým literárnym a spoločenským kontextom prelomu šestdesiatych a sedemdesiatych rokov 19. storočia, ukázat, „ako sa v tomto procese vyhraňovala pozícia Országhovej tvorby, v čom a ako táto tvorba zužitkováva tradíciu a v čom a ako prináša do vývinu slovenskej literatúry užv týchto rokoch prvky nove ${ }^{\text {"5 }}$.

A. Pražák mal na základe svojho blízkeho, osobného poznania Hviezdoslava, ${ }^{6}$ ale aj postupného zhromaždenia autentického pramenného literárneho materiálu priamo od spisovatela (využil ho o. i. v príležitostnej charakteristike neznámych básnických textov $)^{7} \mathrm{v}$ pláne pripravit monografiu s údajným titulom $Z$ psychologie Hviezdoslavova literárního tvořeni, ktorú však nikdy nenapísal. Jej určitou „náhradou“ sa stala publikácia $S$ Hviezdoslavom s podtitulom Rozhovory s básnikom o živote a diele ${ }^{8}$ napísaná síce v češtine už v roku 1949 pri príležitosti stého výročia spisovatel’ovho narodenia, no vydaná nakoniec v slovenskom preklade Gabriela Rapoša až v roku 1955 v Slovenskom vydavatel'stve krásnej literatúry v Bratislave. Aj ked’ má podla slovenských literárnych ohlasov ${ }^{9}$ kniha

3 P. O. Hviezdoslav v liste Albertovi Pražákovi z 28. 8. 1918. In: PRAŽÁK, Albert: S Hviezdoslavom. Rozhovory s básnikom o živote a diele. Text pre slovenské vydanie pripravil Gabriel Rapoš. Bratislava: Slovenské vydavatel'stvo krásnej literatúry, 1955, s. 383.

4 Porov. BUJNÁK, Pavol: Pavol Országh Hviezdoslav. Liptovský Svätý Mikuláš: Tranoscius, 1919; KOSTOLNÝ, Andrej: O Hviezdoslavovej tvorbe. Bratislava: Universum, 1939; PRAŽÁK, Albert: Hviezdoslavovy prvotiny. Literárnohistorický sborník X, 1953, s. 250-279.

5 ŠMATLÁK, Stanislav: Význam básnických počiatkov Pavla Országha Hviezdoslava pre vývin slovenskej poézie. Slovenská literatúra 2, 1955, č. 3, s. 249.

6 Táto štúdia je podstatne doplnenou a rozpracovanou verziou už publikovaného textu, venovaného vztahu A. Pražáka a P. O. Hviezdoslava s odkazom na Pražákovu pozostalost’ a nájdenie rukopisov zo začiatkov básnickej tvorby P. O. Hviezdoslava: ZELENKOVÁ, Anna: Vozraščenie k semejnomu nasledstvu Al'berta Pražaka i Pavlu Orsagu Gvezdoslavu. In: Literature and Social Change: A Voyage Through the History of Slavic Studies. Ed. Lubor Matejko. Bratislava: Porta Danubiana - Univerzita Komenského, 2017, s. 205-212.

7 Napr. PRAŽÁK, Albert: Hviezdoslavove prvotiny. Literárnohistorický sborník, X, 1953, s. 250-279. Tenže: Országhova mad'arská prvotina o Sigetu a Zrinském. Bratislava 1, 1927, s. 538-439 a pod.

8 PRAŽÁK, Albert: S Hviezdoslavom. Rozhovory s básnikom o živote a diele. Bratislava: Slovenské vydavatel'stvo krásnej literatúry, 1955.

9 PIŠÚT, Milan: Albert Pražák a jeho stretnutia s Hviezdoslavom. In: PIŠÚT, Milan: Roky a diela. Bratislava: 
najmä biograficko-memoárový charakter blízky k publicistike a beletrizovaniu, široká materiálová základňa a redundantný poznámkový aparát potvrdzuje využitie klasického literárnohistorického prístupu. Napriek tomu, že danému memoárovému textu bola venovaná dostatočná literárnovedná pozornost', tak nepovšimnutou predsa len zostala podrobná analýza genézy tejto knihy a jej kompozičného usporiadania vyplývajúceho aj z jej komplikovanejšej prípravy, čo sa odrazilo napr. v korešpondencii medzi Pražákom a Hviezdoslavom. ${ }^{10}$ Autor tu ako určitý „virtuálny narátor“ komentuje Hviezdoslavove názory na literatúru, kultúru, umenie, politiku či na viaceré filozofické otázky a mieri od „rodinného rozmeru“ k historicko-sociologickému opisu a zachyteniu slovenskej reality na prelome 19. a 20. storočia v európskych súvislostiach. Pražák sa stretával so slovenským básnikom od roku 1913 až do jeho smrti a pre štúdium jeho diela od neho získal aj úradné dokumenty a vela básnických rukopisov zo začiatkov jeho literárnej tvorby. Tie mali byt na jednej strane podkladom pre pripravovanú monografiu, na druhej strane mali tieto básnické texty prejst Pražákovým kritickým zhodnotením a osobným rozhodnutím, čo by sa mohlo ešte z tohto rozsiahleho konvolútu pripravit na eventuálne dodatočné vydanie.

Redaktor Slovenského vydavatel'stva krásnej literatúry Gabriel Rapoš, ktorý preložil knihu $S$ Hviezdoslavom z češtiny do slovenčiny, bol s Albertom Pražákom v osobnom kontakte a v roku 1954 od neho prevzal súbor Hviezdoslavových básnických textov, ktoré boli potom využité aj v dvoch zväzkoch Básnických prvotín 1-2, edične zostavených Stanislavom Šmatlákom. ${ }^{11}$ Ten v edičnej poznámke k Básnickým prvotinám I. 1868-1869 uviedol, že kompletný rukopisný materiál z raného obdobia Hviezdoslavovej tvorby predstavuje okolo 3000 strán prepísaného textu (spolu s materiálom od A. Pražáka) a obsahuje najmä nedatovanú básnickú produkciu rôznorodej umeleckej hodnoty. ${ }^{12}$ Po Pražákovej smrti v roku 1956 jeho rodina, dcéra Hana a syn Přemysl, splnili želanie svojho otca a slovenský materiál, ktorý ešte zostal v pozostalosti (rukopisy, tlače, korešpondencia, písomnosti slovenskej, českej, mad’arskej a latinskej proveniencie a pod.), postupne odovzdali Rapošovým prostredníctvom do Slovenského vydavatelstva krásnej literatúry a potom do Literárneho archívu Matice slovenskej v Martine. Niektoré archiválie - slovaciká - však v tejto rodinnej pozostalosti predsa len zostali v množstve

Slovenský spisovatel, 1961, s. 414-422. Tenže: Doslov o autorovi a jeho knihe. In: PRAŽÁK, Albert: S Hviezdoslavom. Rozhovory s básnikom o živote a diele. Bratislava: SVKL, 1955, s. 433-441; Na okraj slovenských štúdii Alberta Pražáka. In: PRAŽÁK, Albert: Z literárnych súvislostí. Bratislava: SVKL, 1964, s. 7-17; TOMČÍK, Miloš: Vývin Pražákovho záujmu o Pavla Országha-Hviezdoslava. In: Acta Universitatis Carolinae Philologica 2-4. Slavica Pragensia XII. Na pamět profesora Alberta Pražáka. Praha: Univerzita Karlova, 1970.

10 V slovenskom kontexte sa tejto problematike v poslednom období najviac venoval Miloslav Vojtech, napr. VOJTECH, Miloslav: Albert Pražák a Pavol Országh Hviezdoslav (Nad knihou Alberta Pražáka S Hviezdoslavom). In: VOJTECH, Miloslav: Tvorcovia literatúry a literárnej histórie. Bratislava: Univerzita Komenského, 2013, s. 63-74.

11 HVIEZDOSLAV, Pavol Országh: Básnické prvotiny 1. 1868-1869. Bratislava: Slovenské vydavatelstvo krásnej literatúry, 1955; 2. 1870-1872 a z básni nedatovaných. Bratislava: Slovenské vydavatelstvo krásnej literatúry, 1956.

12 ŠMATLÁK, Stanislav: Poznámky. In: Pavol Országh Hviezdoslav. Básnické prvotiny I. (1868-1869). Bratislava: Slovenské vydavatel'stvo krásnej literatúry, 1955, s. 499. 
písomností „zabudnuté“ (neboli ani archivované), a tak skryté pred literárnovednou verejnostou až do súčasnosti.

Z tejto privátnej a zatial' neznámej Pražákovej pozostalosti, ktorá sa po jeho smrti nachádzala v byte dcéry Hany Drábkovej-Pražákovej, pochádza nález raných rukopisných Hviezdoslavových básní písaných po slovensky a mad’arsky, ktoré sa neobjavili v súbornom knižnom vydaní Hviezdoslavovej poézie a nenachádzajú sa ani v Šmatlákových edíciách z pätdesiatych rokov 20. storočia, ich odpisy nie sú v Literárnom archíve SNK v Martine ani v Oravskom múzeu P. O. Hviezdoslava v Dolnom Kubíne. Nie sú zachytené ani v časopiseckých štúdiách publikujúcich a komentujúcich básnikove doteraz neznáme texty, napr. v článku Ludovíta Petraška Prvotiny a neznáme básne P. O. Hviezdoslava ${ }^{13}$, Pavla Vongreja Zabudnuté verše Pavla Országha-Hviezdoslava ${ }^{14}$ či v článku L. Sziklaya Hviezdoslavove mad'arské prvotiny ${ }^{15}$. Ich doterajšie „pražské“ uloženie v rodinnom archíve dedičov Alberta Pražáka jednoznačne poukazuje na skutočnost', že tieto materiály existujúce mimo slovenský kontext nemohli byt’ v pätdesiatych rokoch k dispozícii editorom Hviezdoslavových spisov, tzn. Stanislavovi Šmatlákovi alebo d’alším vydavatelom a neskorším bádatel’om, ktorí sa zaoberali autorovými prvotinami, išlo napríklad nielen o štúdie Alberta Pražáka, ${ }^{16}$ ale aj Flory Kleinschnitzovej, ${ }^{17}$ Ervína Lazara ${ }^{18}$ a najmä v pätdesiatych rokoch 20. storočia už uvedené doslovy a edičné komentáre Stanislava Šmatláka, ${ }^{19}$ v novšom období štúdia Tibora a Marty Žilkovcov. ${ }^{20}$

Ide o rukopisný súbor niekol'kých desiatok slovenských (ale aj mad’arských ${ }^{21}$ ) básní a konceptov (písaných Hviezdoslavovým rukopisom) - nie všetky básnické texty sú datované. Jednotlivé básne vznikali pravdepodobne v polovici šesṫdesiatych rokov a na

13 PETRAŠKO, Ludovít: Prvotiny a neznáme básne P. O. Hviezdoslava. Literárny archív 15/78, Matica slovenská, 1980, s. 117-210.

14 VONGREJ, Pavol: Zabudnuté verše Pavla Országha-Hviezdoslava. Literárny archív 22, Matica slovenská 1987, s. $46-50$.

15 SZIKLAY, Ladislav: Hviezdoslavove mad’arské prvotiny. Slovenská literatúra 3, 1956, č. 1, s. 37-68.

16 PRAŽÁK, Albert: Hviezdoslavove prvotiny. Literárnohistorický sborník X, 1953, s. 250-279; tenže: Hviezdoslav v Kežmarku. Sborník věnovaný Josefu Jankovi. Usp. Vilém Mathesius - Bohumil Trnka - Ladislav Heger - Vojtěch Jirát. Praha: Klub moderních filologů, 1939, s. 252-265.

17 KLEINSCHNITZOVÁ, Flora: Hviezdoslavove prvotiny básnické. Sborník Matice slovenskej 1, 1923, s. 136-147 a s. $168-171$.

18 LAZAR, Ervín: Prešovské študentské roky Pavla Országha Hviezdoslava. Sborník prác profesorov evanjelického kolegiálneho slovenského gymnázia v Prešove, 1940, s. 71-96.

19 Napr. ŠMATLÁK, Stanislav: Niekolko čŕt $k$ charakteristike Hviezdoslavových básnických prvotín. In: Pavol Országh-Hviezdoslav: Básnické prvotiny 2. 1870-1872 a z básní nedatovaných. Bratislava: Slovenské vydavatel'stvo krásnej literatúry, 1956, s. 525-551; tenže: Hviezdoslavove básnické juvenilie. In: Pavol Országh-Hviezdoslav: Básnické zrenie II. 1881-1884. Bratislava: Slovenské vydavatel'stvo krásnej literatúry, 1958, s. 353-423.

20 ZSILKA, Tibor - ZSILKOVÁ, Marta: Analýza recepcie mad’arskej prvotiny Pavla Országha-Hviezdoslava. In: P. O. Hviezdoslav. Text a kontext. Dolný Kubín - Nitra: Literárne múzeum P. O. Hviezdoslava v Dolnom Kubíne - Kabinet literárnej komunikácie a experimentálnej metodiky Pedagogickej fakulty v Nitre, 1975, s. 133-148.

21 Podrobnej analýze nájdeného rukopisu mad’arských prvotín - konvolútu Topmakö - sme sa venovali v štúdii ZELENKOVÁ, Anna - GBÚR, Ján: Unknown Hungarian First Fruits of the Slovak Poet Pavol Országh Hviezdoslav (A Contribution to the Slovak-Hungarian Bi-literary Stance). Neohelicon, 2017. 
prelome šestdesiatych a sedemdesiatych rokov 19. storočia a nevybočujú z ideového a umeleckého rámca prvej zbierky Básnické prviesenky Jozefa Zbranského, vydanej na konci roka 1868 (obsahovala výber z básnických prvotín realizovaný autorom pod redakciou Viliama Paulinyho-Tótha). V tomto období, o ktorom vypovedá najmä Hviezdoslavova korešpondencia $\mathrm{s}$ jeho učitelom Adolfom Medzihradským, ${ }^{22}$ prešiel začínajúci básnik v roku 1865 z mad’arského Miškovca na gymnázium v Kežmarku, kde v roku 1870 zmaturoval. Na jeseň toho istého roka odišiel na právnickú akadémiu do Prešova, kde sa, ako je všeobecne známe, výraznejšie pokúsil vstúpit do slovenského literárneho života a s Kolomanom Banšellom redigoval almanach Napred (po ukončení štúdia v roku 1872 sa vrátil do Dolného Kubína ako advokátsky pomocník). Jeho slovenské prvotiny, ktoré až na výnimky nie sú datované, svojou poetikou výrazne nevybočujú z vývojového kontextu autora hladajúceho v tomto období adekvátny výraz a estetickú formu pre svoju umeleckú činnost. Stanislav Šmatlák uviedol, že stovky raných rukopisných náčrtkov a básnických variantov zachovaných v Hviezdoslavovej pozostalosti potvrdzujú pracovnú húževnatost', s ktorou básnik prekonával svoje počiatočné nedostatky pri básnení v rodnej slovenčine na úrovni slovníka, gramatiky i syntaxe. ${ }^{23}$

Objavený konvolút slovenských básnických textov a náčrtkov ${ }^{24}$ teda nevybočuje z dobového autorovho kontextu, časovo zodpovedajúceho obdobiu jeho stredoškolských a právnických štúdií, t. j. obdobiu pobytu v Kežmarku a Prešove. Ide o niekolkko disparátnych súborov, ktoré síce vznikali v tomto „mladíckom“ období, ale ako naznačuje ich rukopisná podoba, tak autor tieto básnické texty nepísal v synchrónnom časovom momente, t. j. v bezprostrednej kontinuálnej postupnosti a explicitnej tematickej nadväznosti. Jeho verše sú totiž bud' zachytené v ucelenom súbore, alebo priložené samostatne, i ked' sa aj tu dá v niektorých prípadoch pripustit - s ohladom na spôsob grafického zápisu - ich genetická a chronologická príbuznost́.

Hviezdoslavove slovenské básnické prvotiny, ktoré sa vyrovnávajú s poéziou romantickej generácie, najmä s estetikou Andreja Sládkoviča (jemu bola dedikovaná i prvotina Básnické prviesenky Jozefa Zbranského), prezrádzajú citové pripútanie zatial sa iba formujúceho lyrického subjektu k rodnému kraju, oravskej prírode, ale aj k duchovnému odkazu slovenskej literatúry. Svojím kompozičným usporiadaním a prozodickou realizáciou metrických impulzov, na pomedzí medzi štúrovským sylabizmom a trochejským, resp. daktylotrochejským sylabotonizmom, dokazujú vplyv tvorby A. Sládkoviča. Iba výnimočne sa dá v týchto slovenských textoch rozpoznat náznak jambickej metrickej tendencie, ktorá podla Šmatláka vyplývala z osvojenia si veršovej techniky českých májovcov, najmä J. Nerudu a V. Hálka ${ }^{25}$ - tí akceptovali pravidelné strofické členenie a rytmickou zhodou iktu so slovným prízvukom vyzdvihovali sémanticky dôležité miesta verša a jeho vetnú intonačnú líniu. Neprítomnosť českej motivickosti a jambických impulzov potvrdzuje

22 PRAŽÁK, Albert: Adolf Medzihradský a Pavol Országh. Bratislava 4, 1930, s. 687-709.

23 ŠMATLÁK, Stanislav: Pavol Országh Hviezdoslav. Praha: Svobodné slovo, 1968, s. 16.

24 Nájdeným súborom mad’arských básnických prvotín (konvolút 24 listov zošitých nitou z polovice šesṫdesiatych rokov 19. stor.) sa budeme zaoberat pri inej príležitosti. Pripravuje sa jeho podrobná interpretácia.

25 Porov. ŠMATLÁK, Stanislav: Hviezdoslav. Zrod a vývin jeho lyriky. Bratislava: Slovenské vydavatelstvo krásnej literatúry, 1961, s. 80. 
tézu, že české inšpirácie v hviezdoslavovských prvotinách sa objavovali až na začiatku sedemdesiatych rokov, a to najmä $\mathrm{v}$ súvislosti s osobným poznaním českého kultúrneho prostredia a účastou na jungmannovskej slávnosti v Prahe v roku 1873. ${ }^{26}$

Z hladiska motívov sa básnikove slovenské prvotiny viažu nielen na nevyhnutné folklórne (ponáškové) podnety, ale najmä na zachytenie momentu lásky v najrôznejších podobách. Síce ich spája štylizovaný kánon citovej expresie i konvenčné lexikálne výrazové prostriedky (napr. cyklus Piesne), no napriek tomu tu chýbajú religiózne prvky, a naopak jednoznačne dominuje subjektívna lúbostná lyrika, poukazujúca na básnický talent začínajúceho autora a jeho individuálne zachytenie autentického zážitku. Ten sa prejavil o. i. $\mathrm{v}$ básňach, v ktorých sa prelína prírodná lyrika s lúbostnou tematikou, napr. v reflexívnej meditácii Básnictvo! svätá nadšenost' (názov zvolený podla incipitu) o zodpovednosti a predstave básnika štylizovaného ako človeka so spoločenským poslaním. Aj v básni $O b$ raz prechádza lyrický subjekt v podobe pútnika od osobného smútku k zovšeobecneným úvahám o svete a k pocitu nadosobnej hrdosti. Datovanie je uvedené pri ucelenom súbore troch básní - Deñ narozenia mojho (1872. 2. febr.), napísanom v čase básnikových 23. narodenín, v ktorom autorský lyrický subjekt v rámcovej čierno-bielej symbolike rétoricky apostrofoval seba samého tým, že si kládol otázku zmyslu svojej existencie (odkazujúcej k motívu plačúcej matky) i svojho objektivizovaného neštastného osudu rodnej krajiny, na ktorú „havran si čierny zasadol“. Posledné dve štvorveršové strofy podčiarkujúce piesňové ladenie básnickej reflexie však motívom vychádzajúceho slnka apelujú na matku aj zem, aby „odhodili“ svoj smútok. Druhá i tretia báseň tohto „minicyklu“ (Tatra sa preobliekla a Šumejte, háje, ešte raz!...) vychádzajú z folklórnych podnetov, sú romantickým zachytením krás tatranskej prírody (v prvom texte sa lyrický subjekt ponúka za družbu na svadbe Kriváňa s Tatrou), s ktorou sa básnik bolestne lúči spomienkou a pod’akovaním „,za[...] šumot dúverny““, sprevádzajúci „bujné nádeje“ jeho mladosti.

Za týmito tromi básňami sa v súbore objaveného rukopisného materiálu nachádza rozsahom najväčšia čast̉ s titulom Piesne - obsahujúca 28 básní, z ktorých pät textov má jednostrofickú podobu rukopisného náčrtu, resp. fragmentárneho zápisu. Cyklus prezrádza až intímne súžitie autora s oravskou prírodou, chápanou ako nevyčerpatelný zdroj básnickej obraznosti. Bytostný sklon k lyrizmu, ktorý sa tu intenzívne prejavuje, už na prelome šestdesiatych a sedemdesiatych rokov 19. storočia podla Šmatláka odrážal v Hviezdoslavovej poézii pohlad až „,k nekonečným prostorům kosmu“, ${ }^{27}$ záujem o velké myšlienkové a filozofické koncepcie, podobne ako u jeho českých vrstovníkov Svatopluka Čecha či Jaroslava Vrchlického, ktorých tvorba ho silne ovplyvnila. Protiklad „lásky k národu“ a „’úbostného citu k žene“, prelínajúci sa ako leitmotív v romantickej poézii štúrovcov, sa však u Hviezdoslava formoval pozvolne a súvisel s rodiacou sa predstavou o zmysle poézie, zodpovednosti a o poslaní vlastnej básnickej tvorby. V liste z 22. 9. 1869 svojmu učitelovi Adolfovi Medzihradskému mladý Pavol Országh postuloval svoju koncepciu spoločenského poslania básnika, v ktorom sa musí odrážat „reprezentovaná doba

26 Porov. GBÚR, Ján: Pavol Országh Hviezdoslav a Jan Neruda. Slovenská literatúra 31, 1984, s. 305-324, s. $402-415$.

27 ŠMATLÁK, Stanislav: Pavol Országh Hviezdoslav. Praha: Svobodné slovo, 1968, s. 10. 
$i$ žial’na i radostná utisknutého alebo pozdvihnutého národa“. ${ }^{28}$ Lúbostný motív je velakrát podrobený dezilúziám, ako je to v básňach $\mathrm{Na}$ čo je v srdci láska? alebo Tak bujné mal ja nádeje! (cyklus Piesne); v básni Laskala ma moja mat’ je skutočná láska vztahovaná k materskému citu, k obrazu hladkajúcich mozol'natých rúk matky, ktorá dáva synovi na jeho začínajúcej životnej dráhe ponaučenie, aby zotrval vo viere. Iba výnimočne prebleskne v ohlasových piesňach štylizovaných do jednoduchého dialógu (Odkial že idešs či Krákali, ach krákali...) tendencia k epickosti, ktorá je však zatlačená subjektivizáciou básnikovho vzţahu k prežívanej realite.

Nepochybne sa aj v tejto doteraz neznámej slovenskej rukopisnej tvorbe mladého, začínajúceho básnika lyrická extenzia jeho subjektu pozvol’ne a v rámci programu „napredistov“ emancipuje od dobovej poézie, t. j. od estetickej „konzervatívnej“ normy kladenej na „národnú“ literatúru. Žánrová a tematická pestrost' básnických prvotín súvisí podla S. Šmatláka s autorovým estetickým hl’adiskom, s intuitívnou schopnostou mladého talentu vnímat' kontrast vecí a javov okolo seba. ${ }^{29}$ Tak ako v Básnických prviesenkách Jozefa Zbranského, s ktorými boli pravdepodobne tieto texty s ohladom na analogické motívy, metaforické obrazy aj strofickú výstavbu paralelne písané, tak aj tu sa objavujú antitézy svetla a tmy, dňa a noci, jari a jesene. Kontrapozičné asociatívne kladenie básnických prvkov pritom prináša dramatický pohyb, zmyslovú dynamizáciu väčšinou staticky poňatej lyrickej situácie. Hviezdoslavove fantazijné predstavy, opreté o ,filozofiu, vytekajúcu z hlbokej viery v dobro“, ${ }^{30}$ nie sú obmedzované reálnym priestorom, zostávajú medzi „hviezdami“ a „zemou“; časté pointovanie kontrastných motívov zvyšuje estetický účinok nečakaným striedaním neobmedzeného a nekontrolovatel'ného pohybu (napr. obraz prírodných živlov) a absolútnej nehybnosti. Ak sme už uviedli prevahu lúbostnej a prírodnej lyriky a určitú nezrelost’ a nevyváženost̉ reflexívnej poézie podliehajúcej dobovým manierom, tak je zrejmé, že básnický subjekt pohybujúci sa medzi túžbou a možnostami výrazne naznačuje svojím subjektivizmom talent lyrizujúceho romantika, ktorý cez folklórnu štylizáciu a symbolické rekvizity dedinského života prenikal svojimi obrazmi a metaforami k emocionálnemu uchopeniu disharmonickej sféry „človeka“ a „sveta“, v ktorom je „málo svetla“ a „vel'ký žial““ (báseň Aký ja vel'ký žial' mám!).

Aj ked' tento už neočakávaný, ale dôležitý nález rukopisov básnických prvotín Pavla Országha Hviezdoslava nezmení celkový obraz jeho tvorby, predsa len sa domnievame, že čitatel'ské sprístupnenie týchto textov okrem samotnej heuristicko-biografickej hodnoty rozšíri pohlad slovenskej literárnej histórie na tematickú šírku a žánrovú rozmanitost básnikovej ranej poézie. Tá nielen svojím literárnohistorickým významom, ale aj este-

28 P. O. Hviezdoslav v liste Adolfovi Medzihradskému zo dňa 22. 9. 1869. In: Hviezdoslav z blizka. Výber z listov. Zost. Stanislav Šmatlák. Bratislava: Tatran, 1985, s. 22.

29 ŠMATLÁK, Stanislav: Niekolko čŕt $k$ charakteristike Hviezdoslavových básnických prvotín. In: Pavol Országh-Hviezdoslav: Básnické prvotiny 1. 1868-1869. Bratislava: Slovenské vydavatelstvo krásnej literatúry, 1955 , s. 534.

30 KLEINSCHNITZOVÁ, Flora: Hviezdoslavove prvotiny básnické. Sborník Matice slovenskej 1, 1923, č. 9-10, s. 137. 
tickou hodnotou predznamenala neskoršie autorove vrcholné diela, dnes zarad'ované do zlatého fondu kultúrneho dedičstva slovenského písomníctva. ${ }^{31}$

doc. PhDr. Anna Zelenková, Ph.D.

Slovanský ústav AV ČR, v. v. i.

Valentinská 1, 11000 Praha 1, Česká republika

zelenkova.anna@centrum.cz

31 Podrobnou interpretáciou nájdených slovenských i mad’arských básnických rukopisov z hladiska autorskej poetiky a dobového kontextu sa budeme venovat v ich pripravovanom knižnom vydaní, v spoluautorstve s J. Gbúrom. 
